WZB Discussion Paper

Jens Alber, Ulrich Kohler

\title{
The inequality of electoral participation in Europe and America and the politically integrative functions of the welfare state*
}

July 2008

Order No.:

SP | 2008 - 202

ISSN 1612-3468

Research Area:

Education, Work, and Life Chances

Research Unit:

Inequality and Social

Integration

Social Science Research Center Berlin (WZB)

Reichpietschufer 50, 10785 Berlin

http://www.wzb.eu 
* Forthcoming in: Jens Alber and Neil Gilbert (eds): United in Diversity? Comparing Social Models in Europe and America. Oxford University Press, 2008. 


\section{Abstract}

Electoral turnout is shown to be higher and less socially skewed in member states of the enlarged European Union than in the United States. The differences in the levels of turnout can partly be related to differences in election procedures, but since the procedural rules provide similar incentives or disincentives to all social groups they cannot explain the much higher inequality of electoral participation in America. There is some evidence to sustain the notion that the higher inclusiveness of the West European welfare state fosters political integration and the equality of electoral participation. In line with this notion differences between Europe and America diminish considerably when the analysis is confined to the pensioner generation whose integration into welfare state schemes is largely similar on both sides of the Atlantic. 


\section{Contents}

1 Contrasting images of political participation in Europe and America: The ideas of a European social model and of American exceptionalism 3

2 Levels of electoral participation in Europe and America .................... 6

3 The social inequality of electoral participation ................................ 13

3.1 Voter turnout in different social groups ................................. 13

3.2 The inequality of electoral participation and the inclusiveness of the state

3.3 The inequality of electoral participation among pensioners

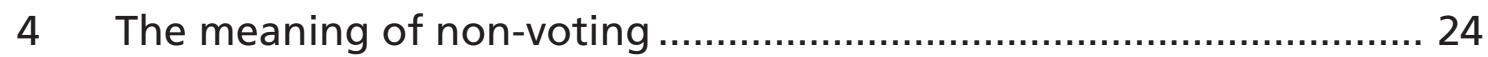

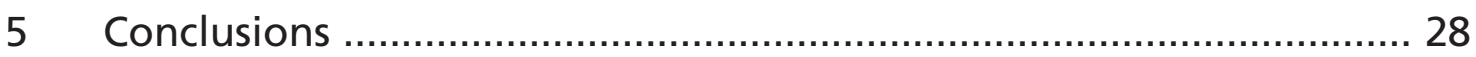

$\begin{array}{ll}\text { Notes } & 29\end{array}$

$\begin{array}{ll}\text { Bibliography } & 30\end{array}$ 


\section{Contrasting images of political participation in Europe and America: The ideas of a European social model and of American exceptionalism}

The Eastern enlargement of the European Union raised the issue to what extent the new member states would follow in the policy footsteps of the old member states rather than taking the United States as their role model. Drawing a polemical distinction between "old" and "new Europe", a former US secretary of defense suggested that the Central and Eastern European countries might adhere more closely to the United States as the super power that helped ending their dependence upon the Soviet Empire. This chapter will examine to what extent patterns of political participation differ between the United States and Europe and where exactly the new member states fit in this comparison.

In a comparative perspective voter turnout in the United States is notoriously low. Why so many citizens of the oldest democracy in the modern world choose to disenfranchise themselves voluntarily is a question that has puzzled sociologists and political scientists for decades. From a rational choice perspective, going to the polls may appear as irrational behavior, because a single vote counts very little and may not be worth the effort of casting a ballot. But why then do the citizens of European democracies participate so much more frequently - and, as we shall see, so much more equally - in elections? Such questions have occupied a central place in comparative political science research upon which we build here with some new comparative data that focus on the degree of inequality of political participation in old and new member states of the European Union as well as in the United States.

Basically, there are two interpretations of the discrepant voting behavior in Europe and America, both of which have normative connotations. From one perspective, which we might call the theory of "American exceptionalism" as first developed by Seymour Martin Lipset (Lipset 1969; Lipset 1996; Lipset and Marks 2000), non-voting is interpreted as not only rational, but also reasonable behavior which is rooted in certain peculiar features of the American political system and of American society which distinguish the United States from Europe. ${ }^{1}$ The other perspective, which we might label the idea of a "European social model" sees the higher turnout in Europe as a result of a higher degree of political integration of the masses which is linked to a more inclusive character of the European state. The "American exceptionalism" school of thought stresses above all the peculiar characteristics of the American political institutions, but also points out features of American society which promote non-voting. ${ }^{2}$ From this perspective, non-voting is typical in a social setting which is marked by the following features: 
- a high level of well-being and basic satisfaction with the way things are going so that people have more interesting things to do than indulge in politics (Lipset 1969: 217);

- many cross-pressures - which are typical for an open society with low class barriers, intersecting group affiliations and high rates of social mobility complicating choice and dampening political emotions (Lipset 1969: 203, 206, 209);

- $\quad$ an active civil society with ample chances for voluntary action which provide alternative forms of political participation to voting, thus diversifying the channels and chances of political action (Lipset 1969: 67; Lipset 1996: 26).

Primarily, however, the "American exceptionalism" perspective links low turnout to specific features of the American political system, above all to peculiarities of the American electoral system which result in a number of disincentives for voting. From this perspective the most important institutional impediments to voting are :

- $\quad$ voting is burdensome requiring a specific act of previous registration (Lipset 1996: 45);

- $\quad$ elections are held on weekdays so that people must get off work in order to vote (Lipset 1996: 45);

- there is a plethora of political offices to be filled by elections, which means that there are many diverse channels of political participation that diminish the desire to participate in any one particular way and get voters tired of the recurrent acts of voting (Lipset 1996: 43);

- $\quad$ the federal system of decision making and the divided form of American government disperse political responsibilities thus making each single act of voting much less relevant than in more centralized political systems (Lipset 1996: 39, 40);

- politics are less relevant to citizens because the scope of state action is more limited, so that crucial decisions structuring people's life chance are basically made in the market sphere (or at least outside the scope of state responsibilities), thus rendering the results of elections comparatively irrelevant (Lipset 1969: 186; Lipset 1996: 27). ${ }^{3}$

There is little reason to assume that the American impediments to voting - which all increase the cost of voting relative to the expected benefits - impinge very differently on specific social classes. As Lipset himself observed, "the more cohesive and stable a democratic system is, the more likely it becomes that all segments of the population will react in the same direction to major stimuli" (Lipset 1969: 33). 
Lipset refers to two additional features fostering political integration, which are also highlighted by proponents of the "European social model". ${ }^{4}$ First he notes that electoral turnout reflects the scope of state action or, as he calls it, the degree of "statism" which influences the relevance of government policies (Lipset 1969: 186; 1996: 27). Secondly, he notes that "the combination of a low vote and a relative lack of organization among the lower-status groups means that they will suffer from neglect by the politicians who will be receptive to the wishes of the more privileged, participating, and organized strata" (Lipset 1969: 216-17). This idea very much resembles the notion of a vicious circle which Piven and Cloward (1988) developed to denote the American political process: The more socially skewed political participation is, and the less lower income groups go to the polls, the less incentive there is for politicians to design policies which consider the concerns of lower classes; and the more policies are geared to the articulated interests of the betteroff, the more the lower classes become politically alienated and turn away from the political process. ${ }^{5}$

The positive mirror image of this negative scenario is what a political system should look like from the perspective of the European social model: On the input side, all citizens participate (more or less) equally, and political office is not only for the rich who can afford the cost of electoral campaigns, but open for everyone, because the costs of elections are partly borne to a large extent by the public purse which distributes public subsidies among the competing parties according to the number of votes they could mobilize. This results in a more representative structure of parliament which reflects the social structure of society without very strong distortions. ${ }^{6}$ On the output side, universal welfare state schemes incorporate the entire population into schemes which provide social rights to all citizens at a level generous enough to avoid that the middle and upper classes opt out to private solutions. Hence, public welfare is neither fragmented into many categorical schemes - which segment political loyalties - nor bifurcated into special targeted schemes for a stigmatized poor part of the population on the one side and more generous schemes for the middle classes on the other. In the European social model public welfare schemes have a dual politically inclusive effect: (1) They foster the political integration of all citizens regardless of income or status, because all citizens have not only the same voting rights but also universal social rights attached to citizenship. (2) Supplementing the market with a second arena for the distribution of life chances, the state not only ameliorates social inequalities in the market sphere, but also gives all citizens - rather than only the rich who are affected by tax cuts or by public investment decisions - an important stake in political decisions thus increasing the salience of politics for everyone. This makes not only for higher levels of political turnout, but also for a fairly equal distribution of turnout across all social strata.

It is impossible here to subject all these propositions similarly to an empirical test. Based on some new comparative data, we can, however, pursue a set of relevant descriptive and analytical issues. On descriptive grounds we can investigate the following aspects: 
- How high is voter turnout in Europe and America, and where do the new member states stand in this respect?

- Is turnout less socially skewed in Europe and how do old and new member states compare to America?

On analytical grounds we will probe the following questions:

- To what extent can cross-national differences in turnout be explained by the institutional rules of the electoral game?

- To what extent do we find social inequalities of political participation which contradict the idea that institutional impediments impinge similarly on all social groups?

- To what extent can cross-national differences in patterns of turnout be related to the inclusiveness of the state, and do differences vanish once the impact of welfare state programs is held constant?

- Is non-voting an indication of political satisfaction and to what extent are its effects counter-acted by other forms of political participation?

\section{Levels of electoral participation in Europe and America}

Following U.S. official statistics, only one in two Americans bothers to vote in U.S. presidential elections. Even though representing the highest level since 1968, the official turnout of the last presidential election on November 7th 2004 just stood at 56.7 per cent (Federal Election Commission 2005a: 5). A proper understanding of these figures, however, requires a certain familiarity with the intricacies of American electoral statistics. ${ }^{7}$ Generally, one expects the turnout rate to equal the number of votes cast divided by the eligible electorate. However, the size of the eligible electorate in the United States is difficult to estimate. Using the size of the population at voting age as denominator, the turnout rates officially reported by the Federal Election Commission considerably underreport turnout, because the voting age population includes resident aliens who do not have the right to vote.

For a proper comparison of American and European turnout rates it is necessary to use turnout rates that are similarly defined. The United States Election project (http:// elections.gmu.edu/; McDonald and Popkin 2001) provides an accurate estimate of the turnout rates based on the voting eligible population (VEP), which is defined as the population at voting-age that actually holds the rights of citizenship. In Figure 1 we 
Figure 1: Voter turnout in the last three national elections (averages)

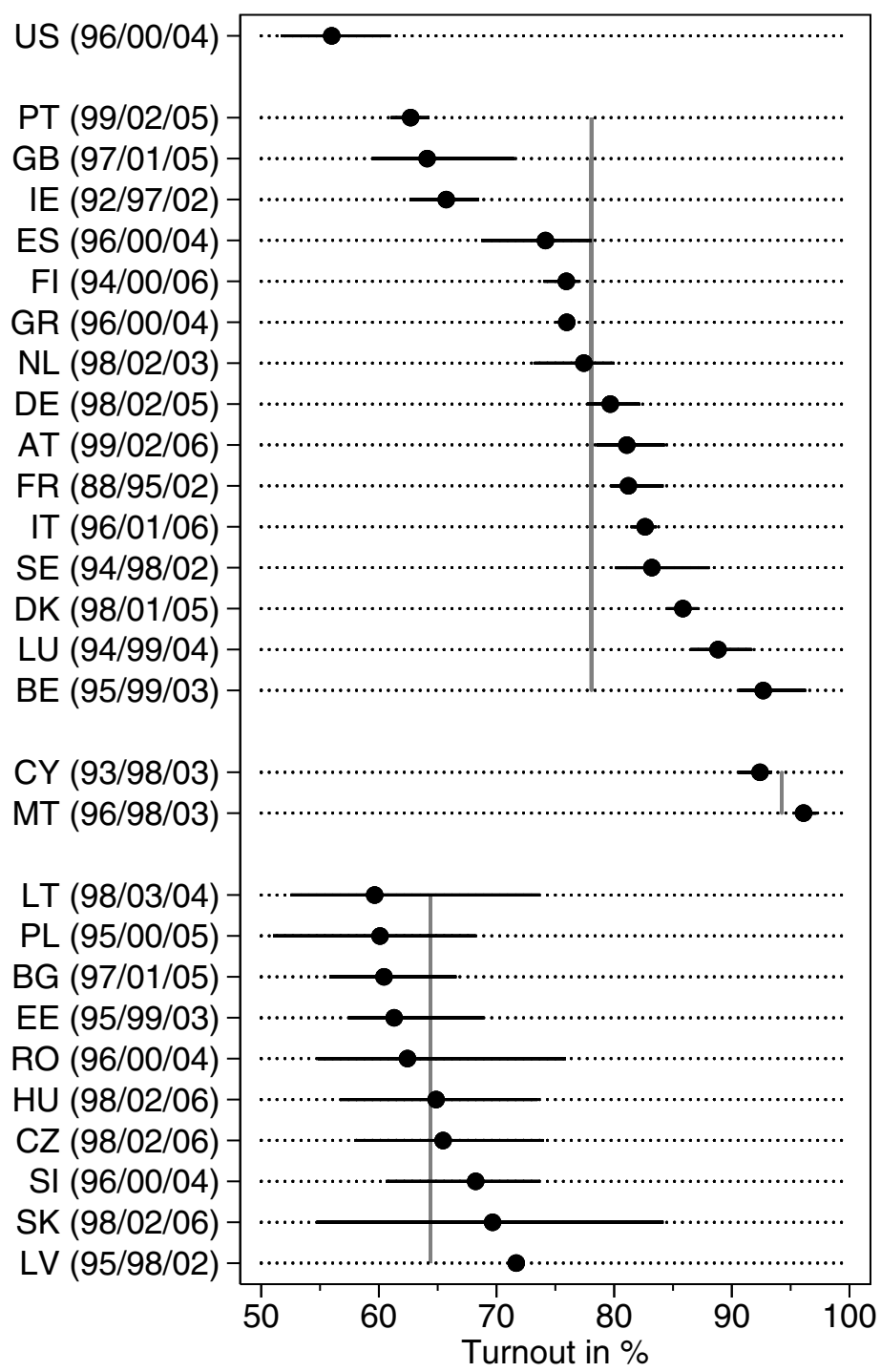

Source: http://www.idea.int/vt/; USA: McDonald/Popkin 2001 and http://elections.gmu.edu/ Country abbreviations according to International Standardization Organisation (ISO 3166)

compare the average turnout during the last three American presidential elections according to this rectified procedure - 56 per cent - with the average turnout rates in the last three national elections of European countries. The European data are provided by the International Institute for Democracy and Electoral Assistance (IDEA; http://www.idea.int/ index.cfm). ${ }^{8}$ The comparison of the American and European figures is based on the 
assumption that the electoral registers of European countries provide complete lists of the voting eligible population. ${ }^{9}$ This seems justified for electoral systems where administrations are responsible for maintaining continuously updated lists of voters, or where registration is compulsory. To the best of our knowledge, this is the case in all European countries except Ireland and Malta.

In Figure 1 we have divided the European countries into three groups. The first group consists of the 15 traditional EU member states, to which we here refer as EU-15, "Western Europe" or "old member states". A second group is formed by the new member states of the European Union which had come under communist rule after World War II but joined the Union in 2003 or 2007 . These countries will be called "post-communist new member states" or "transformation countries". Finally there is a group of two further countries Malta and Cyprus - which belong neither to the old EU nor to the transformation countries and which we grouped together as "Mediterranean periphery countries". To facilitate comparisons between the three European country groups and the U.S., we have calculated group means ${ }^{10}$, which are plotted as vertical lines in the graphs.

The overriding finding illustrated in Figure 1 is that American turnout is low by Western European standards, and that the post-communist new member states are more similar to the United States than to Western Europe. The American turnout of 56 per cent compares to an average turnout of 78 per cent in Western European countries, and to an average of 64 per cent in the transformation countries. Not a single Western European country has turnout rates below the American level, and the United Kingdom ${ }^{11}$, Portugal and Ireland are the only countries to approximate the low American figure. In the case of the postcommunist new member states the averages based on the three last elections conceal that fact that turnout has recently been shrinking. Averaging 71 per cent in the first election after the transformation which we covered here, turnout has declined to 59 per cent in the most recent one, thus being only slightly above the American level.

The question then is how we can explain these differences. Do they reflect differences in the inclusiveness of the state, as proponents of the European social model would suggest, or are they merely the result of different election procedures resulting in voter fatigue, as theorists of "American exceptionalism" would have it? In order to capture the impact of different election systems, we have compiled some key characteristics of the institutional setting in which elections are embedded (Table 1). The table lists for each election for which we present comparative turnout data the timing of the event - weekend or workday -, the branch of government which was elected - legislative (parliamentary) or executive (presidential) -, whether voting was compulsory or not, whether registration for voting was an administrative act or required a special individual effort, the type of electoral system which prevailed in each country, the degree of competitiveness of the election, and how many parties held more than 5 per cent of the seats in the national parliament. ${ }^{12}$ What follows is a brief discussion of the likely impact which each of these factors exerts on turnout. 
Table 1: Institutional characteristics of elections

\begin{tabular}{|c|c|c|c|c|c|c|c|c|}
\hline & $\begin{array}{l}\text { Average } \\
\text { turnout }\end{array}$ & $\begin{array}{c}\text { Election } \\
\text { on } \\
\text { weekend }\end{array}$ & $\begin{array}{c}\text { Electoral } \\
\text { branch }\end{array}$ & $\begin{array}{l}\text { Com- } \\
\text { pulsory } \\
\text { voting }\end{array}$ & $\begin{array}{l}\text { Bureau- } \\
\text { cratic } \\
\text { registrati- } \\
\text { on }\end{array}$ & $\begin{array}{c}\text { Electoral } \\
\text { system }\end{array}$ & $\begin{array}{l}\text { Compe- } \\
\text { titiveness }\end{array}$ & $\begin{array}{l}\text { No. of } \\
\text { parties }\end{array}$ \\
\hline US $(96 / 00 / 04)$ & 56 & No & Exec. & No & No & FPTP & 3 & 2 \\
\hline РT (99/02/05) & 63 & Yes & Leg. & No & Yes & List PR & 10 & 4 \\
\hline GB (97/01/05) & 64 & No & Leg. & No & Yes & FPTP & 8 & 3 \\
\hline IE $(92 / 97 / 02)$ & 66 & No & Leg. & No & No & STV & 15 & 3 \\
\hline ES (96/00/04) & 74 & Yes & Leg. & No & Yes & List PR & 6 & 2 \\
\hline $\mathrm{FI}(94 / 00 / 06)$ & 76 & Yes & Exec. & No & Yes & List PR & 5 & 5 \\
\hline GR $(96 / 00 / 04)$ & 76 & Yes & Leg. & Yes & Yes & List PR & 3 & 2 \\
\hline $\mathrm{NL}(98 / 02 / 03)$ & 77 & No & Leg. & No & Yes & List PR & 6 & 6 \\
\hline DE $(98 / 02 / 05)$ & 80 & Yes & Leg. & No & Yes & MMP & 3 & 4 \\
\hline АТ $(99 / 02 / 06)$ & 81 & Yes & Leg. & No & Yes & List PR & 4 & 4 \\
\hline FR (88/95/02) & 81 & Yes & Exec. & No & Yes & TRS & 26 & 3 \\
\hline IT $(96 / 01 / 06)$ & 83 & Yes & Leg. & Yes & Yes & List PR & 2 & 5 \\
\hline SE (94/98/02) & 83 & Yes & Leg. & No & Yes & List PR & 20 & 6 \\
\hline DK $(98 / 01 / 05)$ & 86 & No & Leg. & No & Yes & List PR & 6 & 6 \\
\hline LU $(94 / 99 / 04)$ & 89 & Yes & Leg. & Yes & Yes & List PR & 11 & 5 \\
\hline BE (95/99/03) & 93 & Yes & Leg. & Yes & Yes & List PR & 2 & 10 \\
\hline EU-15 & 78 & & & & & & 8 & 5 \\
\hline CY $(93 / 98 / 03)$ & 92 & Yes & Exec. & Yes & Yes & List PR & 5 & 4 \\
\hline МТ $(96 / 98 / 03)$ & 96 & Yes & Leg. & No & No & STV & 4 & 2 \\
\hline Med. Periph & 94 & & & & & & 5 & 3 \\
\hline LT (98/03/04) & 60 & Yes & Exec. & No & Yes & Parallel & 5 & 4 \\
\hline $\mathrm{PL}(95 / 00 / 05)$ & 60 & Yes & Exec. & No & Yes & List PR & 16 & 6 \\
\hline BG $(97 / 01 / 05)$ & 60 & Yes & Leg. & No & Yes & List PR & 22 & 4 \\
\hline EE $(95 / 99 / 03)$ & 61 & Yes & Leg. & No & Yes & List PR & 8 & 6 \\
\hline RO $(96 / 00 / 04)$ & 62 & Yes & Exec. & No & Yes & List PR & 15 & 5 \\
\hline HU $(98 / 02 / 06)$ & 65 & Yes & Leg. & No & Yes & MMP & 2 & 2 \\
\hline CZ (98/02/06) & 65 & Yes & Leg. & No & Yes & List PR & 4 & 4 \\
\hline SI $(96 / 00 / 04)$ & 68 & Yes & Leg. & No & Yes & List PR & 15 & 5 \\
\hline SK $(98 / 02 / 06)$ & 70 & Yes & Leg. & No & Yes & List PR & 5 & 7 \\
\hline LV (95/98/02) & 72 & Yes & Leg. & No & - & List PR & 3 & 6 \\
\hline NMS 10 & 64 & & & & & & 10 & 5 \\
\hline
\end{tabular}

Holding elections on a weekend rather than on a workday is frequently assumed to reduce the costs of participation, thus leading to higher turnout rates in countries with weekend elections (Lijphart 1997; Oppenhuis 1995; Franklin 2004). ${ }^{13}$ Table 1 shows that only four European countries follow the example of the United States in scheduling elections on workdays (United Kingdom, Ireland, the Netherlands, and Denmark). ${ }^{14}$ Average turnout 
in these four countries amounted to 73 per cent which is 17 percentage points higher than the American rate. This suggests that the scheduling of elections alone cannot account for the American turnout gap.

National elections also differ according to the branch of government for which the voters cast their ballot. We here aimed at elections for the legislative branch of the democracy, i.e. at elections to the national parliament. Some countries, however, also elect the executive branch (i.e. the president) directly, and we consider presidential elections as a "first order election" whenever the President has not merely representative functions but also plays an important role in forming the government or in exercising executive power. This is the case not only in the United States, but also in Finland, France, Lithuania, Poland, and Romania. ${ }^{15}$ The three transformation countries with executive elections have lower turnout rates than the other post-communist countries (61\% vs. 66\%), whereas the two Western European countries with presidential elections do not differ sizably from other EU-15 countries (79\% vs. $78 \%$ ). Hence, the American turnout remains low from a European perspective even if we compare the United States only to Western European countries with executive elections.

Compulsory voting effectively boosts electoral participation even in countries where non-compliance does not result in specific punishments. Greece, Italy, Luxembourg, Belgium, and Cyprus all have compulsory voting. ${ }^{16}$ Average turnout in the four Western European countries with compulsory voting amounted to 85 per cent, compared to 76 per cent in the other old member states. Even if we abstract from countries with compulsory voting, the remaining Western European countries thus have much higher turnout than the United States.

The methods of voter registration have an impact on turnout because countries differ with respect to the institutional hurdles they put in front of the citizens. Whereas some countries hold individual citizens responsible to register for elections, so that the initiative rests with the individual, others make public administrations responsible for maintaining lists of eligible voters and for contacting them prior to the election. The more individual initiative is required for registration, the higher is the hurdle or the effort it takes to participate. Comparative data on this crucial difference are rather difficult to obtain. The best respective source to our knowledge is the expert survey of the "ACE Electoral Knowledge Network" (http://aceproject.org/). Even this source cannot give a clear indication of the cost it takes the voter to get registered in practice. It does, however, provide information as to whether registration lists are obligatory or not. Assuming that countries which do not have obligatory registration put higher responsibilities on individual voters, we take this as a rough proxy for the individual effort required to register. Ireland is the only EU-15 country that resembles the United States in not having compulsory registration and it also stands out for its low electoral turnout. ${ }^{17}$ This suggests that differences in registration procedures may indeed account for some of observed national differences in electoral participation. 
With respect to electoral procedures, it is often argued that due to the "winner take all" principle many votes are wasted in countries with majority vote. From this perspective, turnout should be higher in proportional systems than in majority systems (Oppenhuis 1995; Powell 1986). Table 1 lists which of the two basic types prevails in each country and also gives a more fine-grained differentiation in brackets based on a classification proposed by the International Institute for Democracy and Electoral Assistance. First Past The Post (FPTP) and Two-Round Systems (TRS) are two variants of majority systems. List Proportional Representation (LPR) and Single Transferable Vote (STV) are variants of proportional election systems. Finally, Mixed Member Proportional Systems (MMP) and parallel systems combine majority and proportional systems, but are here counted as proportional systems. ${ }^{18}$ Based on the crude dichotomous distinction, the table provides two central results: (1) In Europe proportional systems are much more widespread than majority systems. (2) These systems also tend to have higher rates of turnout (79\% vs. 73\%). ${ }^{19}$ A closer analysis of the two Western European countries with majority systems, i.e. France and the United Kingdom, shows that this cannot fully explain the EuropeanAmerican turnout gap. Despite their similar electoral systems, France and Britain have widely discrepant turnout levels, and participation in France is much higher than in the United States.

The competitiveness of the election is another potential determinant of turnout. If the election result is believed to be narrow, the expected weight of the individual vote is presumably perceived to be higher. To the extent that rational voters compare the costs and benefits of voting, the expectation of a narrow election result should thus increase voter turnout (Gray/Caul 2000, Jackman 1987; Kirchgässner 1990; Powell 1986; for a discrepant assessment see also Ferejohn/Fiorina 1975). In Table 1 the competitiveness of the election is measured by the absolute difference between the two strongest parties or candidates. The smaller this difference, the closer should be the political battle. By this yardstick, election results were very narrow in the most recent American presidential elections as well as in some European elections. A simple bivariate linear regression analysis of the data shows that the degree of competitiveness increases turnout within each country group. For the Western European countries, every percentage point of increasing closeness boosts turnout by 0.07 percentage points. For Eastern Europe the respective coefficient is 0.17 percentage points, and for the two Mediterranean countries it is even 0.76 percentage points. The predicted turnout for a hypothetical Western European country with the competitiveness level of the United States would be 78 per cent ${ }^{20}$ which is much higher than the observed American level of 56 per cent. Hence, taking the competitiveness of elections into account would even increase the gap in voter turnout between Western Europe and the U.S.

The last column in Table 1 shows how many parties obtained more than five per cent of the votes in the national election. In a multi-party system, small parties are able to tailor their policies to the demands of specific groups. Consequently, turnout should be higher than in systems with only few parties which are less able to appeal to specific voter 
interests. Table 1 shows that the American political system is essentially a two-party system, while Greece, Spain, Hungary, and Malta are the only European countries with two party systems. The United Kingdom, Ireland, and France are similar in also having only a limited number of parties. Analyzing the relationship between turnout and the number of parties by means of bivariate regression shows that multi-party systems tend to have higher turnout. In Western Europe, each additional party increases turnout by 2.8 percentage points, in the post-communist countries the respective increase amounts to 0.88 points. The predicted value for a Western European country with only two parties is 71 per cent. Even though this is lower than the average turnout we actually observe, it is still 15 percentage points higher than the observed American level.

We conclude that none of the institutional factors regarded here can explain the European-American turnout gap alone. The question then is if the ensemble of institutional characteristics related to electoral procedures helps to understand differences in turnout. There are two ways to analyze this problem. The first one is to compare the U.S. turnout figure only to Western European countries that are institutionally very similar. A simple way to find most similar countries is to count the number of arrangements that are different from the U.S. ${ }^{21}$ Judged by this yardstick, the Western European countries which are most similar to the U.S. are the United Kingdom, Ireland, and France. All three countries have distinctly higher turnout than the United States, although Britain and Ireland stand out for their comparative low levels of turnout within the old EU-15. Hence the result is ambiguous, as some but not all of the observed turnout gap between Europe and America can be related to differences in the institutional rules of the game.

A second way to trace the combined impact of institutional regulations is to use a linear regression of turnout on all institutional characteristics to predict what turnout level a Western European country would have if it had all the properties of the United States. A hypothetical Western European country with the properties of the American electoral system would have a turnout of 63 per cent. Even though this is much lower than the observed Western European average of 78 per cent, it is still six percentage points higher than the actually observed American level of 56 per cent.

To a certain extent, then, our analysis provides empirical support for Lipset's assertion that the low electoral turnout in America must be interpreted as a result of peculiar features of the American electoral system which lower the incentive to go to the polls. However, these institutional factors cannot account for the entire participation gap. In addition Lipset assumed that institutional incentives impinge similarly upon all social groups. If all voters are rational actors who similarly weigh the costs and benefits of electoral participation as impinged by institutional impediments for registration on the one side or by the likely impact of one's vote given the closeness of the political competition on the other, we should expect turnout to be roughly similar across all social strata. If, on the other hand, voter turnout reflects the inclusiveness of the political system, we should expect American and European turnout to be perhaps similar among the higher strata, but more different among the lower strata whom we expect to be politically more integrated in Europe due to the more 
representative shape of the input side of the political process, and the more encompassing and universal welfare state arrangements on the output side. From this perspective, we would also expect a rather low degree of inequality in political participation in Europe, but a high degree of polarization in America where welfare state schemes are less encompassing and more bifurcated with more generous entitlements for the middle classes on the one side and more stingy categorical entitlements for specific lower class groups on the other (Klass 1985; Glazer 1988), while political representation on the input side is more skewed in favor of higher income strata. In short, we expect turnout among the higher strata to be similar in Europe and America, while we expect the turnout of lower strata to be higher in the more inclusive European welfare states. The following analysis of the social distribution of voting and non-voting examine to what extent the data bear out these expectations.

\section{The social inequality of electoral participation}

Turnout rates may be low because all groups of a society abstain similarly from voting, or because specific groups fail to participate. Our first empirical question thus is if the European-American turnout gap is the same throughout all social groups or if it systematically varies by social class. In other words, we ask which groups produce the observed gap: Those at the bottom, at the top, or at the middle of the income and skill distribution.

\subsection{Voter turnout in different social groups}

A comparison of the social stratification of voter turnout has to rely on surveys. These surveys should fulfill a number of conditions. First, and most obviously, they must contain reliable measures of electoral participation and of socio-economic position. Second, the samples should cover at least the entire eligible population of each country; or, if more than the eligible population is covered, there must be information which allows us to restrict the analysis to potentially eligible voters. Finally, all data should be measured in comparable ways throughout all countries under observation. Unfortunately, there is not a single survey which meets all these conditions. The two international comparative survey 
programs which come close to meeting all standards - the International Social Survey Programme (ISSP) and the Comparative Study of Elections Systems (CSES) - both have only incomplete coverage of European countries. The only survey program with a complete coverage of all EU member states is the "European Quality of Life Survey" (EQLS), which does not include the United States. The European Social Survey (ESS) offers high quality data for a broad, yet incomplete, set of European countries, and also fails to include the United States. In all these survey programs non-voters are under-represented, either because of a systematic under-coverage of non voters, or because social desirability considerations affect the answering behavior.

Using averages of all available suitable surveys, Table 2 shows how turnout varies by income and education (the number of surveys is given in brackets). The first three columns give the percentage of voters in the lowest, middle, and highest income quintiles (based on equivalent household income), and the columns 4-6 show the respective figures for people at three different levels of education.

The overall result is that the higher social strata tend to participate very similarly in all countries. The participation of the lower social strata varies widely, however, being much higher in Europe than in America. With respect to income, turnout of those in the top income quintile is 83 per cent in the U.S., compared to 88 per cent in Western Europe and 81 per cent in the post-communist countries. In the lowest income quintile only 55 per cent go to the polls in America, while turnout in Europe stands at 79 percent in the EU-15 and at 71 per cent in the Eastern new member states. The Czech Republic, Estonia, and Poland are the only countries where the lower strata abstain from voting to a similar degree as in the United States. The same pattern results with respect to education. Among those with the highest educational degree the American turnout rate of 86 per cent is very similar to the average turnout rate of highly educated people in Western Europe $(88 \%)$ or in the ten Eastern European new member states (86\%). Vast differences appear among those with little schooling. Whereas only 46 per cent of poorly educated Americans go to the polls, the respective figures for their European peers are 81 per cent in Western Europe and 71 per cent in the transformation countries. The United States thus stand out for their remarkably high inequality of electoral participation.

It is beyond the scope of this chapter to examine what policy consequences result from the differences in political participation in Europe and America. We must assume, however, that the actual voters form - together with the masters of investment decisions who can resort to the exit rather than the voice mechanism of political influence - the relevant reference group for politicians who seek office or re-election. The fact that voting is so much more socially skewed in America than in Europe means that the median voter in European countries resides at a much lower point in the social structure than the median voter in the United States. In order to rally half of the electorate behind them, European politicians must thus dig much further down in the structure of social inequality than the political elites in America. As Figure 2 shows, the income position of American voters is higher than in any European country. If they want to win elections, European politicians 
Table 2: Turnout by social class (numbers represent average results of different surveys)

\begin{tabular}{|c|c|c|c|c|c|c|c|}
\hline & $\begin{array}{l}\text { No. of } \\
\text { surveys }\end{array}$ & 1st Quint. & $\begin{array}{l}\text { Income } \\
\text { 2nd_4th } \\
\text { Quint. }\end{array}$ & $\begin{array}{c}5^{\text {th }} \\
\text { Quint. }\end{array}$ & Low & $\begin{array}{l}\text { Education } \\
\text { Inter- } \\
\text { mediat }\end{array}$ & High \\
\hline US & 4 & 55 & 72 & 83 & 46 & 69 & 86 \\
\hline AT & 5 & 78 & 85 & 91 & 78 & 85 & 91 \\
\hline $\mathrm{BE}$ & 5 & 89 & 91 & 94 & 88 & 90 & 93 \\
\hline $\mathrm{DE}$ & 7 & 81 & 89 & 93 & 77 & 90 & 95 \\
\hline DK & 5 & 91 & 94 & 95 & 89 & 94 & 96 \\
\hline ES & 7 & 82 & 83 & 84 & 83 & 79 & 85 \\
\hline $\mathrm{H}$ & 5 & 72 & 80 & 89 & 77 & 77 & 88 \\
\hline FR & 5 & 73 & 79 & 84 & 80 & 76 & 80 \\
\hline GB & 5 & 67 & 72 & 74 & 74 & 69 & 75 \\
\hline $\mathrm{GR}$ & 3 & 91 & 91 & 91 & 92 & 88 & 91 \\
\hline IE & 5 & 77 & 82 & 82 & 80 & 79 & 84 \\
\hline IT & 2 & 86 & 93 & 92 & 88 & 94 & 95 \\
\hline LU & 3 & 62 & 79 & 84 & 70 & 79 & 77 \\
\hline $\mathrm{NL}$ & 7 & 84 & 90 & 91 & 84 & 90 & 94 \\
\hline PT & 7 & 74 & 74 & 80 & 74 & 72 & 80 \\
\hline SE & 7 & 83 & 89 & 94 & 86 & 85 & 93 \\
\hline EU-15 & & 79 & 85 & 88 & 81 & 83 & 88 \\
\hline$C Y$ & 3 & 95 & 93 & 98 & 98 & 88 & 95 \\
\hline MT & 1 & 99 & 97 & 92 & 100 & 96 & 98 \\
\hline Med. Periph & & 97 & 95 & 95 & 99 & 92 & 97 \\
\hline BG & 3 & 72 & 78 & 77 & 77 & 73 & 82 \\
\hline$C Z$ & 7 & 58 & 68 & 71 & 57 & 67 & 82 \\
\hline $\mathrm{EE}$ & 2 & 56 & 68 & 78 & 54 & 63 & 78 \\
\hline HU & 7 & 73 & 81 & 87 & 74 & 86 & 94 \\
\hline LT & 1 & 84 & 87 & 84 & 85 & 84 & 92 \\
\hline LV & 3 & 73 & 77 & 83 & 64 & 75 & 89 \\
\hline $\mathrm{PL}$ & 7 & 57 & 66 & 71 & 57 & 70 & 78 \\
\hline RO & 1 & 91 & 89 & 88 & 92 & 89 & 89 \\
\hline SI & 5 & 75 & 81 & 84 & 75 & 78 & 85 \\
\hline SK & 4 & 74 & 84 & 83 & 74 & 83 & 88 \\
\hline NMS-10 & & 71 & 78 & 81 & 71 & 77 & 86 \\
\hline
\end{tabular}

must thus tailor their policies more to the concerns of lower strata than their American counterparts who can afford to be more receptive to "the wishes of the more privileged, participating, and organized strata" (as Lipset 1969: 216 put it in the line we quoted above).

The question then is why political participation is so much less skewed in Europe. In the next two sections we investigate to what extent the more equal distribution of electoral participation in Europe may be related to the higher inclusiveness of the European state(s). 
Figure 2: The average position of voters in the national income distribution

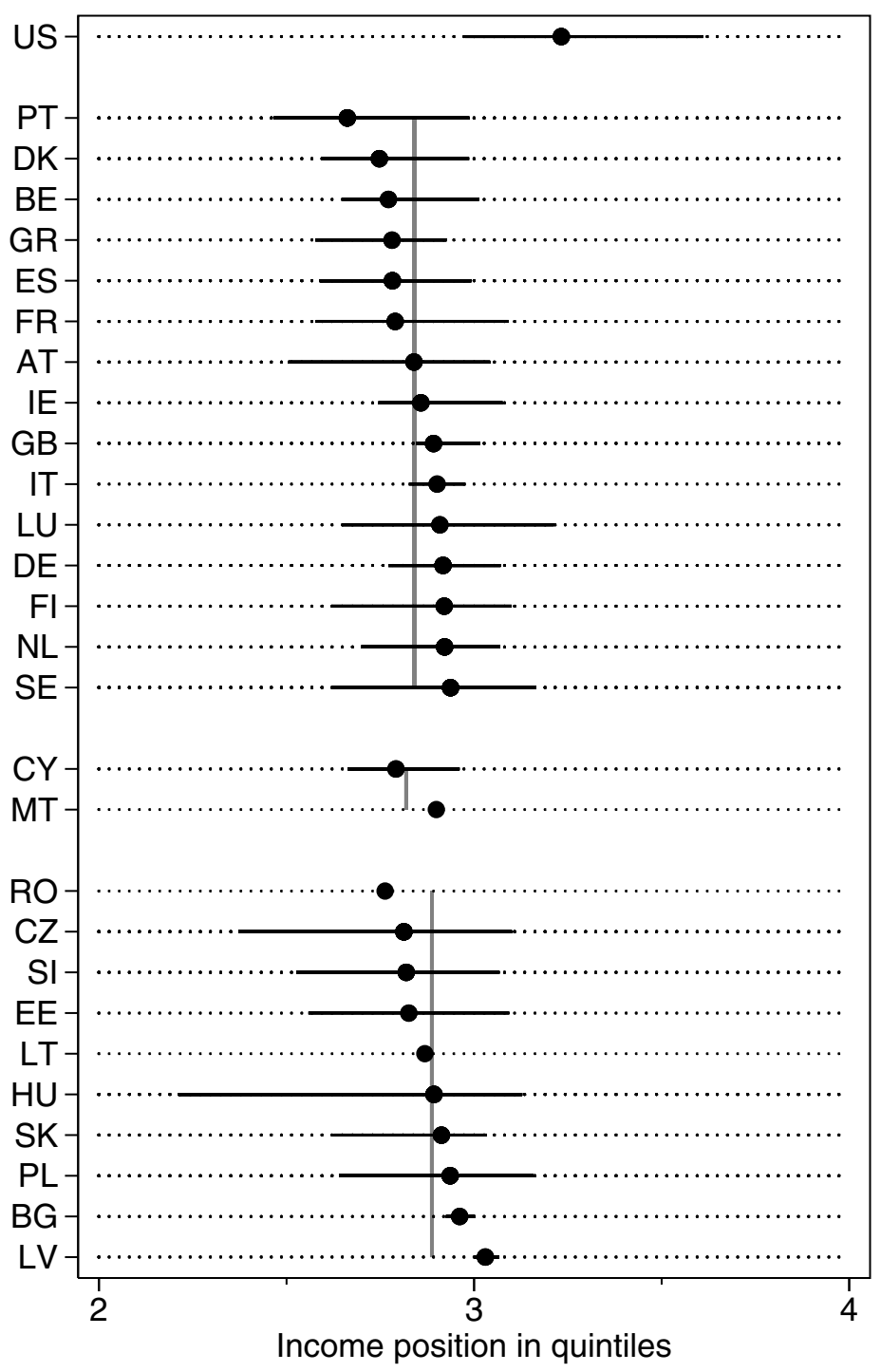

Sources: CSES I, CSES II, ISSP '04, ISSP '02, ESS '02, ESS '04, EQLS '03 


\subsection{The inequality of electoral participation and the inclusiveness of the state}

Based on Table 2 in the previous section, the dots in Figure 3 show the turnout gap which separates higher and lower social strata (calculated as the simple difference in turnout). In order to capture the variability of survey results, the figure also displays horizontal lines showing how far the results of different surveys are apart. The longer these lines are, the more insecurity there is in our knowledge of the degree of polarization in a given country. The major finding of the previous section is clearly re-iterated, however: Turnout inequality is higher in the United States than in any other country under observation. Judged from data of four different surveys (ISSP 2002, ISSP 2004, CSES I, CSES II), electoral participation in the highest American income quintile is between 35 and 22 percentage points higher than in the lowest income quintile. For Western Europe the gap is less than 10 percentage points on average, and Finland is the only country for which we find at least one survey that produces a gap of a magnitude similar to the United States. ${ }^{22}$ Even the Eastern European countries which stood out for their comparatively low overall turnout do not reach the American level of inequality in electoral participation.

If Lipset's assumption that all segments of the population will react similarly to major stimuli in cohesive and stable democratic systems is right (Lipset 1969: 33), the remarkable social inequality in voting cannot be attributed to the impact of institutional settings. Conceptually there is little reason to assume that institutional hurdles impinge very differently on specific social groups, empirically there is no statistical association. As the example of the Eastern European countries shows, low overall turnout need not necessarily translate into high inequality of electoral behavior. Moreover, those Western European countries which are institutionally most similar to the United States - France, Ireland, and the United Kingdom - do not show a comparable level of turnout polarization. In fact, these countries even show relatively small inequality of electoral participation. A more formal statistical comparison of the degree of polarization in America and Western Europe also reveals the extraordinarily high degree of inequality in America. If we insert a hypothetical country with the same institutional characteristics as the United States into the regression for Western European nations, we statistically predict a gap of 9.5 percentage points, whereas the actually observed difference in the United States is 33 points. ${ }^{23}$ Hence, institutional features of the election system may travel a certain distance in explaining cross-national differences in overall turnout, but they cannot explain why turnout is so much more unequal in the United States than in Europe.

Proponents of the European social model would relate the differences to the greater inclusiveness of the state in Europe. In order to test this hypothesis, we have compiled some indicators which tap state characteristics on the output side of the political process. These indicators are presented in Table 3, together with a summary measure of the degree of inequality expressed as the average of the two results for income and education differentials. 
Figure 3: The inequality of electoral participation in the dimensions of income and education

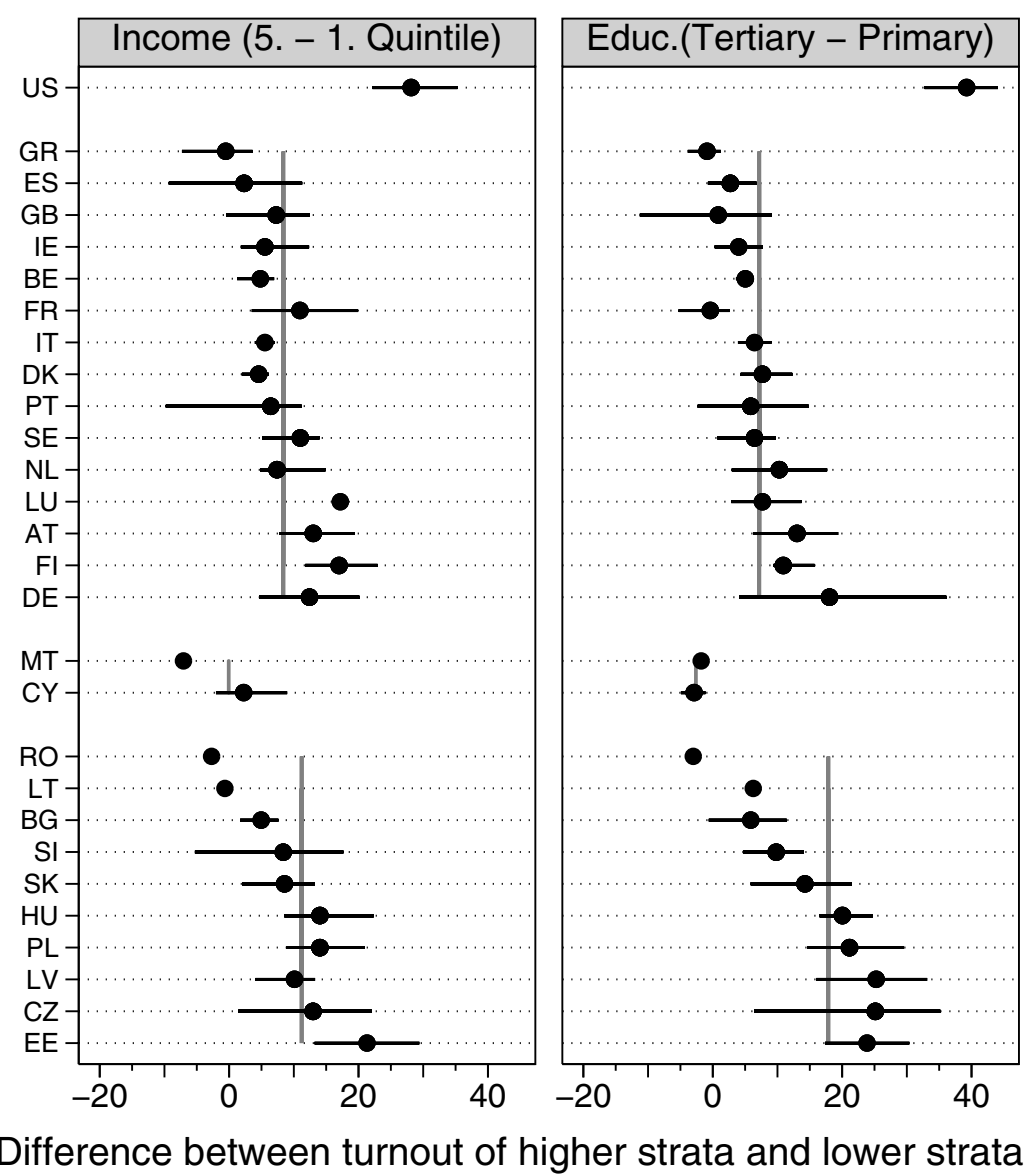

Sources: CSES I, CSES II, ISSP '04, ISSP '02, ESS '02, ESS '04, EQLS '03

For the input side, for which there are few comparable data we can only trace if political parties get direct or indirect state support for the funding of election campaigns. ${ }^{24}$ For the output side we have used two indicators which capture the scope of the tax and welfare state: a) total tax revenues expressed as a percentage of GDP, b) the social expenditure ratio, expressed in gross and net terms (Adema and Ladaique 2005). ${ }^{25}$ The more public funding there is for elections, the less effective campaigning is confined to candidates or parties who can mobilize huge sums of private money, and the more widespread appeal there probably is to voters from all social strata. On the output side, we would expect more universal welfare states - which have more encompassing social programs that provide benefits to all citizens free of stigma - to appeal to all social strata similarly. Even though 
Table 3: Overall polarization and indicators for inclusiveness

\begin{tabular}{|c|c|c|c|c|}
\hline & $\begin{array}{c}\text { Electoral } \\
\text { polarization }\end{array}$ & $\begin{array}{c}\text { Social } \\
\text { expenditure } \\
\text { (gross) as \% of } \\
\text { GDP }\end{array}$ & $\begin{array}{c}\text { Social } \\
\text { expenditure } \\
\text { (net) as \% of } \\
\text { GDP }\end{array}$ & $\begin{array}{l}\text { Total tax } \\
\text { revenue as \% } \\
\text { of GDP }\end{array}$ \\
\hline US & 34 & 15 & 23 & 26 \\
\hline GR & -1 & 25 & & 35 \\
\hline ES & 3 & 20 & 17 & 35 \\
\hline GB & 4 & 24 & 23 & 36 \\
\hline $\mathrm{FR}$ & 5 & 30 & 27 & 43 \\
\hline $\mathrm{BE}$ & 5 & 27 & 23 & 45 \\
\hline $\mathrm{IE}$ & 5 & 15 & 12 & 30 \\
\hline PT & 6 & 23 & & 34 \\
\hline $\mathrm{IT}$ & 6 & 25 & 22 & 41 \\
\hline DK & 6 & 30 & 22 & 49 \\
\hline SE & 9 & 31 & 26 & 50 \\
\hline $\mathrm{NL}$ & 9 & 25 & 22 & 38 \\
\hline LU & 12 & 22 & & 38 \\
\hline AT & 13 & 28 & 22 & 43 \\
\hline $\mathrm{FI}$ & 14 & 26 & 20 & 44 \\
\hline DE & 15 & 28 & 28 & 35 \\
\hline EU-15 & 7.4 & 25 & 22 & 40 \\
\hline $\mathrm{MT}$ & -4 & 19 & & \\
\hline$C Y$ & 0 & 18 & & \\
\hline Med. Periph. & -2 & 19 & & \\
\hline RO & -3 & & & \\
\hline $\mathrm{LT}$ & 3 & 13 & & \\
\hline$B G$ & 5 & & & \\
\hline $\mathrm{SI}$ & 9 & 24 & & \\
\hline SK & 11 & 18 & 17 & 30 \\
\hline $\mathrm{HU}$ & 17 & 20 & & 38 \\
\hline $\mathrm{PL}$ & 18 & 22 & & 34 \\
\hline LV & 18 & 13 & & \\
\hline$C Z$ & 19 & 20 & 18 & 38 \\
\hline EE & 23 & 13 & & \\
\hline NMS 10 & 12 & 18 & 18 & 35 \\
\hline
\end{tabular}

only a very crude measure, the gross social expenditure ratio is used here as a proxy for more inclusive welfare states. The effect of the net social expenditure ratio, which also includes occupational welfare programs and tax subsidies, should be less straightforward, because the benefits thus defined are distributed less equally or come as categorical entitlements with a stigma and thus incorporate the lower classes less effectively into the political order. 
With respect to campaign financing, the U.S. stands out as a country which limits its scarce public funding to presidential elections. ${ }^{26}$ It is also the country with the highest degree of electoral inequality. Further cross-national analysis is impeded by the fact that all European countries have varieties of more or less generous public funding, but more precise comparative information on the quantity of public funding is lacking.

Statistical comparisons with respect to the output side of state action are possible, because social expenditure ratios do show considerable cross-national variation. The American gross social expenditure ratio of 15 per cent compares to an average of 25 per cent in Western Europe and to a mean slightly below 20 per cent in the transformation countries. In this sense the higher degree of polarization may be related to different scopes of welfare arrangements. However, there is also considerable variation within Europe. Figure 4 presents an analysis of the association between social expenditure ratios and the inequality in turnout. Country groups are plotted with different marker symbols in the scatter plots of the figure, and a non-parametric regression line ${ }^{27}$ illustrates the relationship between the two variables for each group. The result is that there is hardly any statistical association. In Western Europe, electoral inequality stays more or less the same regardless of the level of gross social expenditure. In Eastern Europe there is some indication for a higher polarization in countries with less developed welfare states. However, the degree of electoral inequality is much lower in these countries than in the US despite the fact that some of them have similarly low levels of social spending.

Practically the same finding results if we measure the scope of state action by the revenue share in GDP. While the United States does have a lower revenue ratio than any European country for which we have data, there is considerable variation within Europe which is not associated with the degree of inequality in electoral participation. The other two indicators for inclusiveness - the net social expenditure ratio and the pension expenditure ratio - neither show the U.S. to have exceptional values, nor do these measures correlate with the inequality of electoral participation within country groups.

With respect to the majority of the indicators shown in Table 3, the United States appears as having a less encompassing state than European countries. As long as we lack a European country with similarly low scope of state action, however, we cannot really test whether it is the inclusiveness of the state that produces the patterns in electoral participation, or rather some other factor. If we put both indicators of the scope of state activities - i.e. the gross expenditure ratio and the revenue share - together into a multiple regression, the American pattern of electoral behavior is not explained by the data. A hypothetical Western European country with as limited a welfare state as the U.S. would have a statistically predicted turnout inequality of 3.7 percentage points, while the observed American gap is actually 34 percentage points.

The macro-comparisons based on crude indicators of state action thus fail to provide convincing evidence for the hypothesis that universal welfare state programs and a more inclusive state foster the political integration of all citizens. However, there is also a possibility to test the hypothesis with reference to micro-comparisons of various groups 
Figure 4: The inequality of electoral participation in countries with different scopes of state action

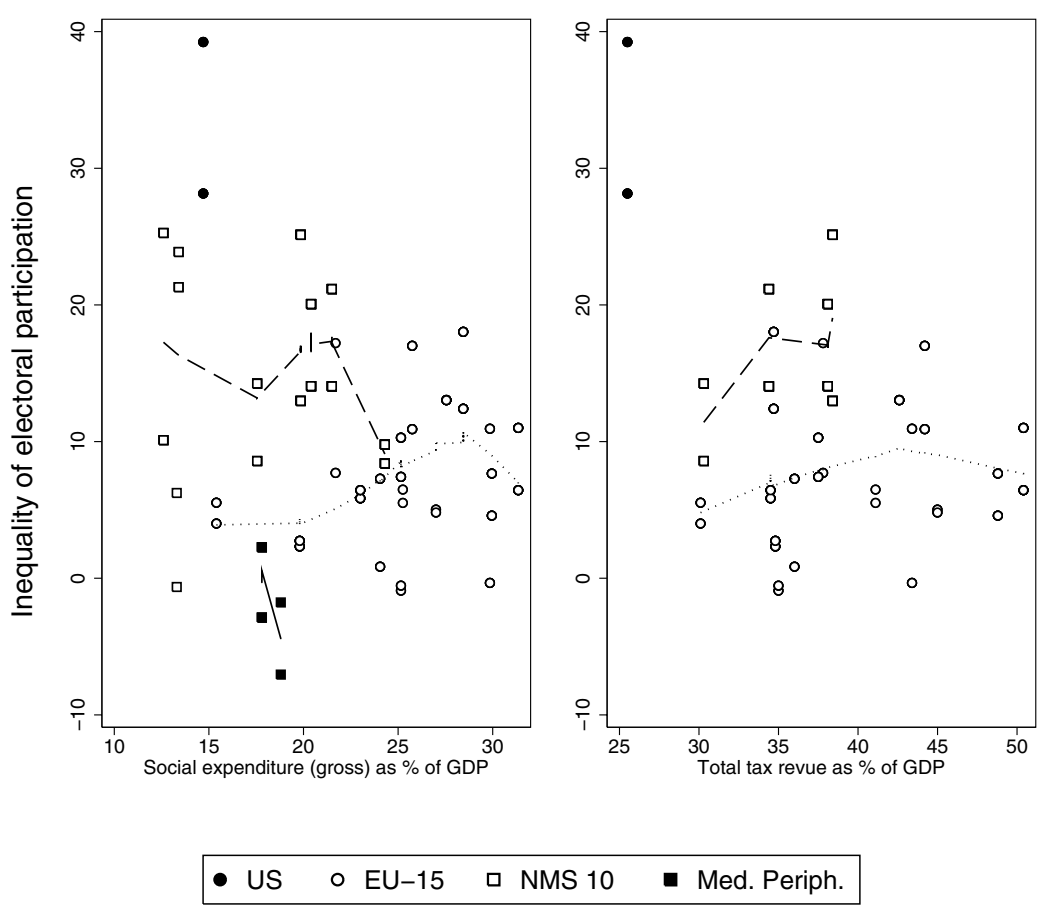

Sources: CSES, ISSP, ESS, EQLS (inequality of electoral participation); OECD, Eurostat (Indicators of scope of state action)

of respondents within countries. If encompassing welfare states are more politically inclusive thus leading to a lower degree of turnout inequality, we would expect EuropeanAmerican differences to vanish among population groups for which the welfare state arrangements on both sides of the Atlantic are rather similar. 


\subsection{The inequality of electoral participation among pensioners}

The United States have an encompassing social security scheme providing similarly universal and fairly generous benefits as European pension schemes in old age, as well as a Medicare scheme providing public health to the pensioner generation. Hence we should expect the population above retirement age in America to display a much less socially skewed pattern of electoral participation and to become more similar to their European peers than the younger generation. ${ }^{28}$ In Europe, in contrast, we would not expect the degree of electoral polarization to vary sizably between age groups as all age-cohorts are similarly incorporated into welfare state schemes.

Figure 5 compares the turnout inequality within the pensioner generation - i.e. respondents who are 65 and older - to the turnout of people at prime working age 30-64 (excluding the group of youngest voters who generally stand out for their low turnout). The dots show the level of inequality for the younger age group, while the arrows point to the electoral polarization among the elderly.

It results that the degree of electoral inequality is much smaller for pensioners in the U.S., whereas older and younger cohorts in Europe do not differ much in their degrees of polarization. Concerning the inequality with respect to education there are only three European countries - Austria, Germany and Latvia - that approximate the American pattern. Concerning the polarization with respect to income, only four other countries France, Luxembourg, Slovakia and Czech Republic - display a similar tendency as the U.S. Hence, the United States is the only country for which we consistently find lower turnout inequality in the pensioner generation than in the working-age generation, regardless of which dimension of social inequality is examined. This also implies that the degree of electoral inequality among old Americans is much more similar to Western European standards than among the young who are not similarly attached to universal welfare programs in America. The differences between Europe and America do not vanish completely among the elderly population. Yet a difference of 42 percentage points among the younger age groups is reduced to a gap of merely 25 points in the pensioner generation who are similarly incorporated into welfare state schemes as their peers on the other side of the Atlantic. This sustains our impression that more inclusive state institutions foster political integration with more widespread and less socially skewed electoral participation. 
Figure 5: Turnout inequality in the pensioner generation and the younger generation

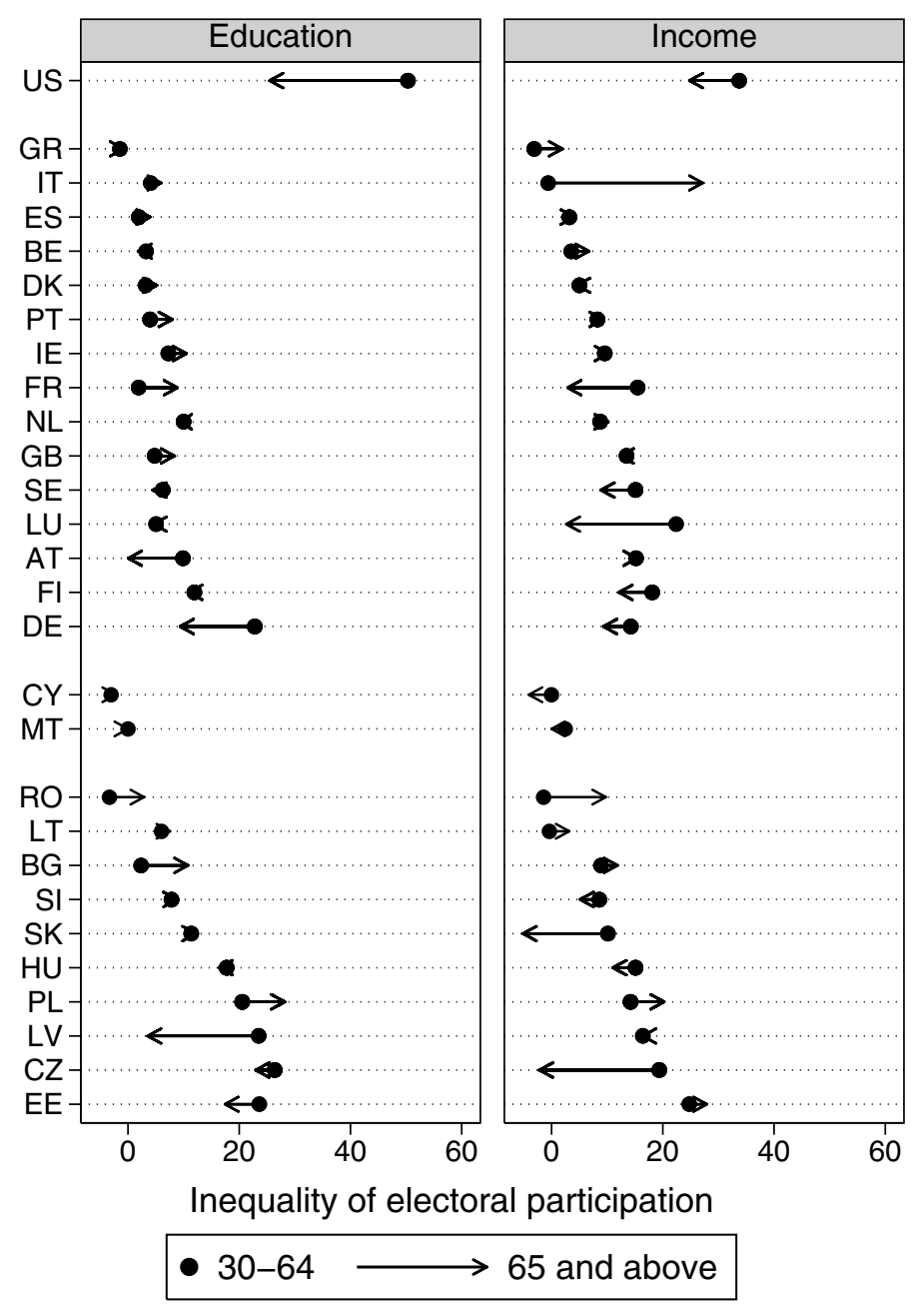

Sources: CSES I, CSES II, ISSP '04, ISSP '02, ESS '02, ESS '04, EQLS '03 


\section{$4 \quad$ The meaning of non-voting}

Voting can only be interpreted as an indication of successful political integration if it can be demonstrated that non-voters are politically more alienated than voters, and that nonvoters also resort less frequently to other forms of political participation so that abstention from the act of voting is not compensated by other and perhaps even more engaging forms of political action. Hence we will examine a) if voting is associated with political satisfaction or rather coupled with dissatisfaction, and b) to what degree voting goes together with or is an alternative to other forms of political engagement.

To what extent can non-voting be interpreted as a sign of satisfaction with the political status quo which induces people to indulge in more interesting things than voting? On the macro-level, we find that low rates of electoral turnout are not a typical characteristic of more affluent nations. In Europe, turnout is high in rich countries like Denmark, Sweden, or the Netherlands, but relatively low in the poorer countries of Central Eastern Europe and of southern Europe. On the individual level, we can examine more directly if political satisfaction breeds voting or abstention from the polls. Based on data from the two CSES modules, the ESS of the years 2002 and 2004, and the ISSP of 2004, Figure 6 shows the difference in electoral participation of people who are politically satisfied with the way democracy works in their country and those who are not, ${ }^{29}$ controlling for gender, age, household income and employment status. The result of this analysis is that politically satisfied citizens are more likely to go to the polls than those who are dissatisfied. Hence it is not true that satisfied people have more interesting things to do than indulge in politics. By participating in elections, politically satisfied people apparently express their loyalty to the prevailing political order, while more alienated people abstain from voting. This sustains our notion that high turnout may be interpreted as a sign of successful political integration.

The question then is to what extent non-voting is compensated by other forms of lawful political action. Figure 7 shows the proportion of respondents who had contacted a politician in the last year, who worked together with other people in an activity group, or who participated in a protest march or demonstration in the previous year. Two results stand out. First, Americans contact politicians more frequently than Europeans and while shying away from participation in a protest march they are also more likely to work together with other people in activity groups. ${ }^{30}$ A closer look reveals, however, that these alternative forms of participation are distributed just as unequally as the act of voting. Rich and better educated citizens contact politicians more frequently, they also engage in activity groups more often, and they even are more likely take part in demonstrations than poor or lower educated people. Analyses not shown here for reasons of space reveal that the inequality 
Figure 6: The difference in turnout of politically satisfied and dissatisfied groups

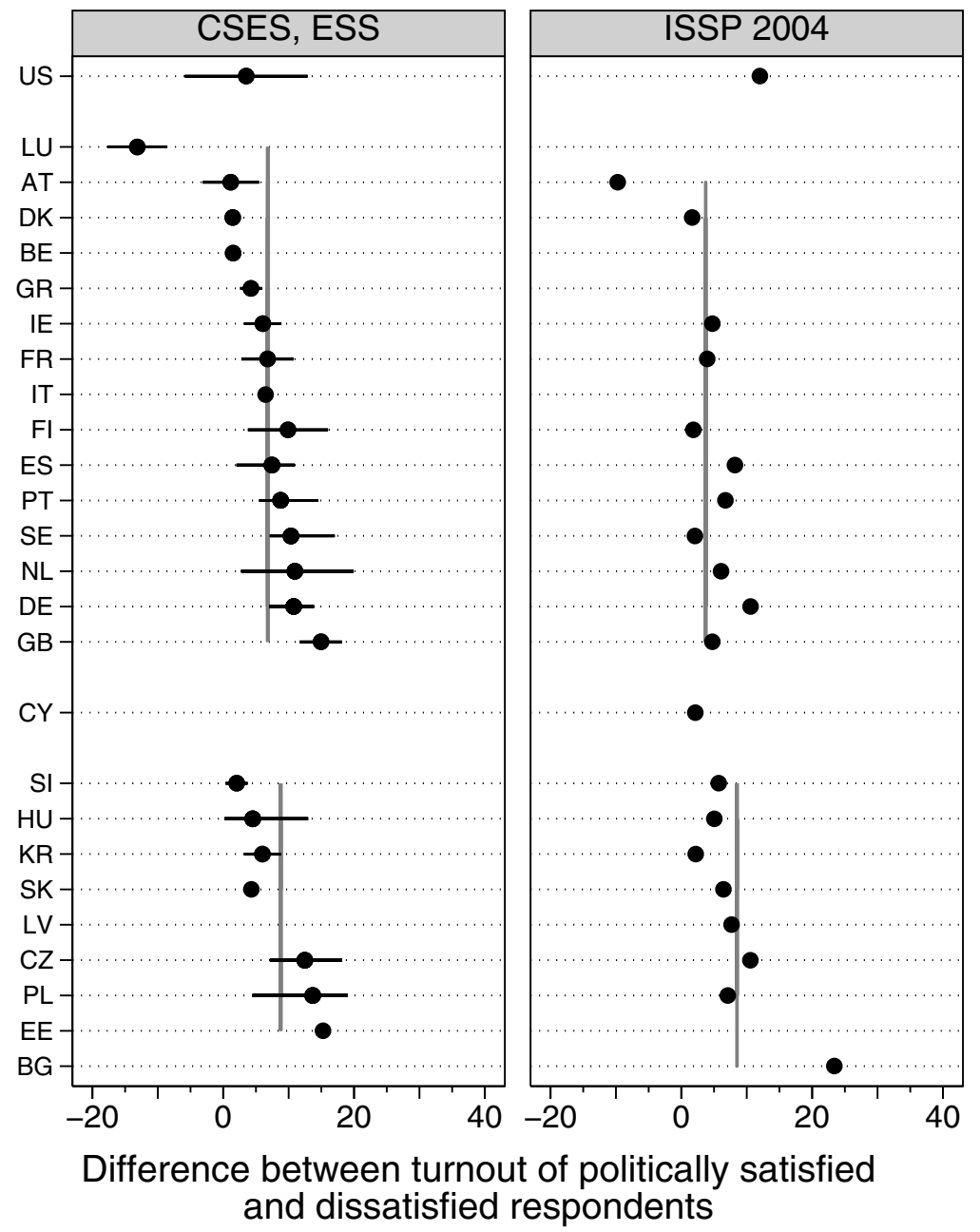

Sources: CSES I, CSES II, ESS '02, ESS '04, ISSP '04

of these alternative forms of political participation is higher in the US than in European countries. The crucial finding from our perspective is, however, that non-voters use alternative forms of political behaviour less frequently than voters. 
Figure 7: Participation rates in alternative forms of political action

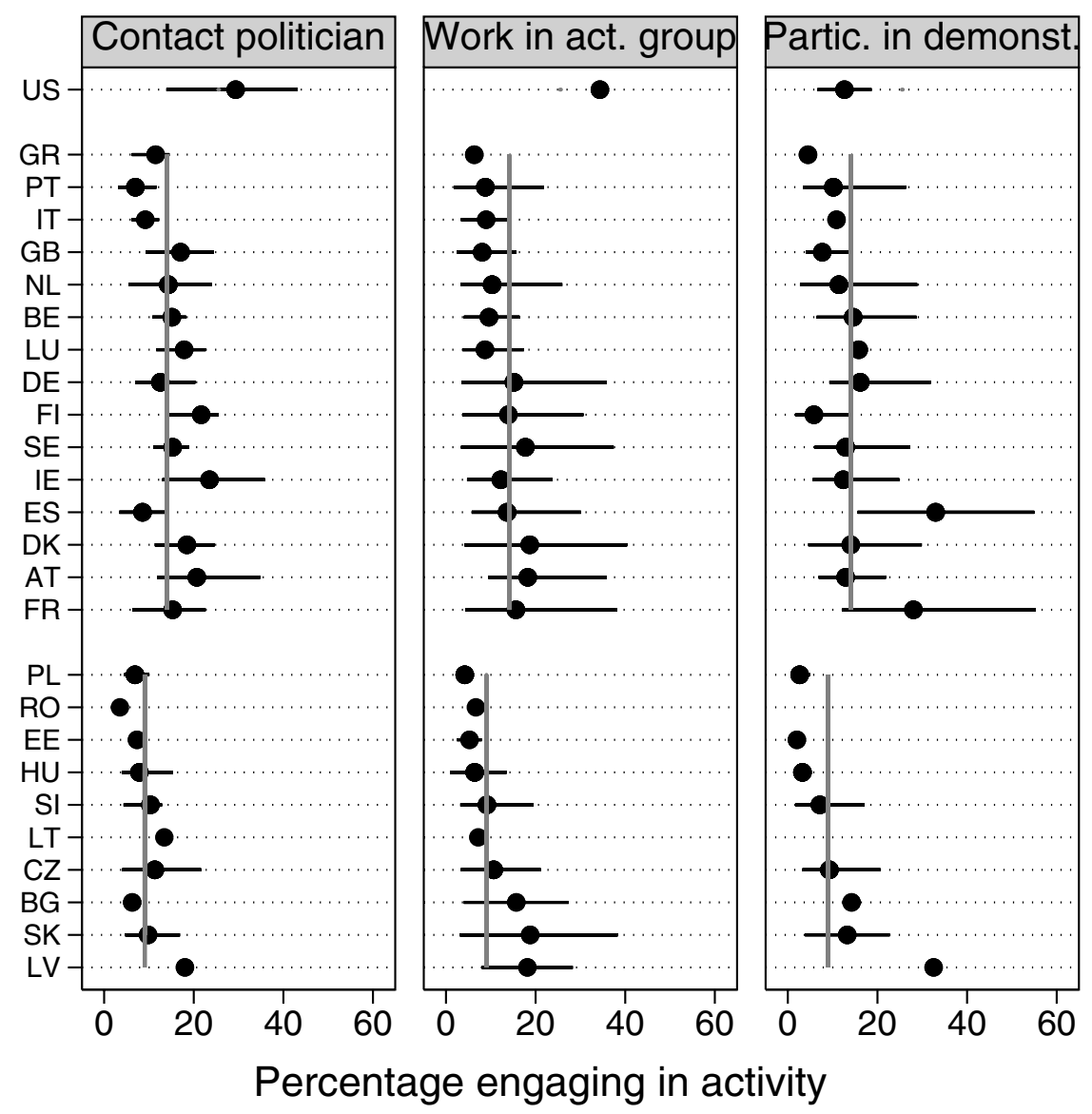

Sources: CSES I, CSES II, ESS '02, ESS '04, EQLS '03, ISSP '04

Figure 8 shows to what extent the fraction of political activists among voters differs from the fraction of participants among non-voters. It reveals that in practically all countries voters engage more frequently in other forms of political action than non-voters. Obviously, different forms of political participation feed on each other rather than serving as substitutes. However, also the other forms of political participation are more socially skewed in America than in Europe. Hence the high inequality in political involvement in America is not confined to the act of voting but extends to other forms of engagement as well. In this sense, inequalities of political participation reinforce rather than compensate each other in the United States. 
Figure 8: Participation in alternative forms of political action among voters and non-voters

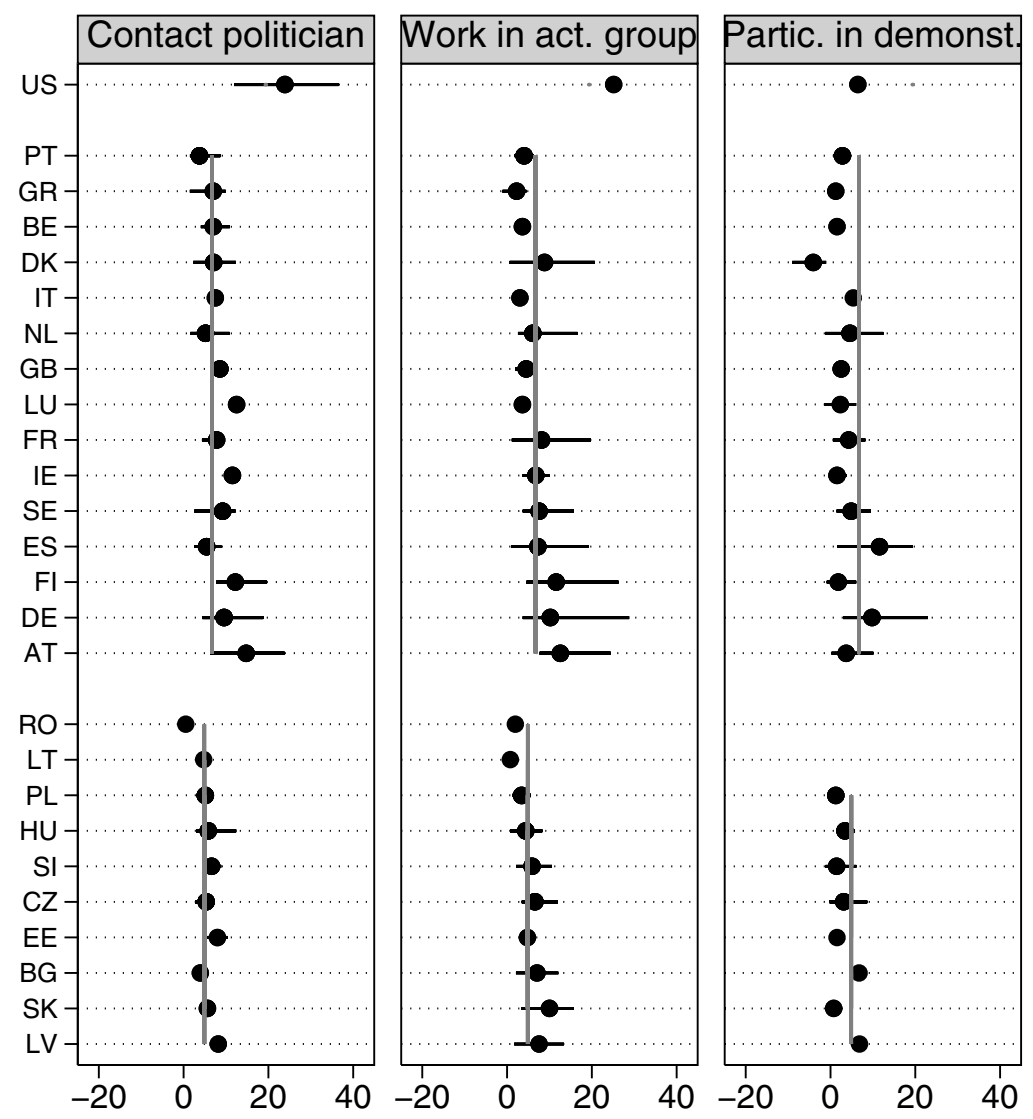

Difference of political engagement between voters and non-voters

Sources: CSES I, CSES II, ESS '02, ESS '04, EQLS '03, ISSP '04 


\section{Conclusions}

We have shown that electoral turnout is higher and less socially skewed in Western Europe than in America. The differences in the levels of turnout can partly be related to differences in election procedures, but since election procedures provide similar incentives or disincentives to all social groups they cannot explain the much higher inequality of electoral participation in America. There is some evidence to sustain the notion that the higher inclusiveness of the (Western) European State(s) fosters political integration and the equality of electoral participation. In line with this notion differences between Europe and America diminish considerably when the analysis is confined to the pensioner generation whose integration into welfare state schemes is largely similar on both sides of the Atlantic.

In many respects, the new member states of the European Union stand at the crossroads between those two poles. While the level of turnout is rather low and has been shrinking in recent years, the inequality of electoral participation is still much lower than in the United States. It is up to national policy makers to decide which of the two rather distinct models of political participation in democracies they find more appealing for their countries. They should be aware of the political implications of their choices, however. If the aim is to foster widespread political participation and to give citizens across all social strata similar weight in the political process, then there are reasons to follow the Western European rather than the American variety of democracy. 


\section{Notes}

1 For more recent synthetic literature building on Lipset's pioneering work see Lijphart (1997); Wilensky (2002, chapter 11 and 18); Verba (2003).

2 Condensing various arguments found in Lipset's work (especially Lipset 1960 and Lipset 1996), the following account gives a stylized summary of the "American exceptionalism" school of thinking which basically started with Sombart's (1906) book on "Why is there no socialism in the United States" and Wells' book on "The Future in America" (1906) of the same year. Lipset himself would not have necessarily subscribed to our stylized account of his position as he usually weighed arguments and counter-arguments in a complex and differentiated fashion frequently referring to alternative hypotheses.

3 Another factor worth noting is that in America some two million citizens over eighteen who are in prisons or who are ex-convicts are disqualified from voting (Shipler 2004: 287). The American prison population in federal or state prisons increased from 0.3 million in 1980 to 1.4 million in 2004. This number does not include prisoners in local jails whose number increased from 182,000 to 714,000 . The size of the total population in prison, jail, on probation, or on parole increased from 1.8 million to 7 million by 2004 (U.S. Census Bureau 2007: 209).

4 As far as we know, there is no publication which explicitly relates the idea of a European social model to particular features of electoral turnout. Rather we have "constructed" this interpretation here quasi as the incarnation of "the European dream" (Rifkin 2004) which has perhaps found its most explicit expression in indirect form in the negative mirror image which Piven and Cloward $(1988 ; 2000)$ described with reference to the American political system.

5 For empirically based qualifications of this view comparing the policy orientations of voters and nonvoters see Shaffer (1982) and Bennett and Resnick (1990). Both studies found the differences to be not very big even though the latter research showed nonvoters to be more in favor of spending on welfare programs; see also Leighly and Nagler (2007) for the rather limited effects of deunionisation on turnout decline.

6 Comparative data on the social structure of European parliaments in historical perspective are given in Best and Cotta (2000) and Best (2007). Neither of these sources reports the income of parliamentarians, while both highlight the growing over-representation of university graduates in the post-war period. In the American Congress at least one third of all Senate members were millionaires in 1997, whereas the number of millionaires in the House amounted to over 60 (Davidson/Oleszek 1998: 210). An Internet source gives the percentages of millionaires for 2003 as $40 \%$ for the Senate, and $28 \%$ for the House (http://www.cnn.com/2003/ALLPOLITICS/06/13/ senators.finances/); this compared to a stated proportion of millionaires in the population of $1 \%$ (http://www.commondreams.org/headlines04/0630-05.htm). This high over-representation of affluent groups in the American Congress is related to the very high cost of election campaigns. In the election cycle 2003-04 the average cost of wining a seat in the Senate was reported as 2.6 mio dollars, while the average for a seat in the House was 531.000 dollars (Davidson/Oleszek 2006: 67).

7 For an elaboration see Alber (2000), McDonald and Popkin (2001).

8 We have used the most recent "first order" election of each country for which IDEA provides data, i.e. the election which is perceived as the key nation-wide election by the voters.

9 Basing international comparisons of electoral statistics on the number of votes expressed as a percentage of the eligible population does not completely eliminate all pitfalls in comparisons, because countries may differ in their liberalism with respect to granting the rights of citizenship. Thus countries which restrict citizenship rights - for example by barring prisoners, ex-convicts or the resident alien population from voting - make the denominator of the fraction smaller than countries which grant rights more generously.

10 Country group averages were calculated by summing up the turnout rates of each country of the country group and dividing by the number of countries without weighting for population size.

11 Following the convention of ISO 3188, we use the abbreviation "GB" for the United Kingdom in our tables and graphs.

12 While Table 1 reports average national turnout during the last three elections, the following discussion of the impact of institutional factors refers to the specific institutional setting 
characterizing each respective election taking all three national elections into account.

13 The extent to which weekday elections actually increase the cost of voting hinges very much upon the opening hours of the ballot boxes.

14 A number of countries, primarily in Eastern Europe, hold their elections on two consecutive days. These elections were classified as weekend elections, if one of these days was a Saturday or Sunday.

15 In these countries turnout was higher in the presidential elections than in elections of the parliament which sustains our notion that the former constitute first order elections.

16 Austria, which has compulsory voting in only two of its states (Vorarlberg and Tirol) was here classified as a country without compulsory voting.

17 For countries without compulsory registration, it is not entirely clear if turnout rates are based on all eligible voters in the denominator or only on the number of registered voters.

18 Detailed descriptions of these various electoral systems may be found on the IDEA web site under http://www.idea.int/esd/glossary.cfm.

19 Based on an analysis of 147 elections, this result has also been demonstrated by the International Institute for Democracies and Electoral Assistance (http://www.idea.int/vt/survey/ voter turnout8.cfm).

20 This value results if the average American competitiveness score of 3.47 is entered into the regression equation for Western European countries.

21 Differences in competitiveness and the number of parties were weighted so that the highest observed difference amounted to one, while smaller observed differences were expressed as fractions of this maximum difference.

22 This refers to the results of the ISSP 2004 (23 percentage points). The values of the other surveys are: 19 (EQLS), 16 (ISSP 2002), 15 (ESS 2002) and 12 (ESS 2004).

23 This refers to the average gap in both dimensions of social inequaliy resulting from all considered surveys.

$24 \mathrm{http}: / / \mathrm{www}$.aceproject.org/epic-en/pc.

25 For the European OECD countries, the data listed in the table report the average value of the gross social expenditure ratio for the years 2001 (Adema and Ladaique 2005) and 2004 (http:// epp.eurostat.ec.europa.eu/). For the U.S. we have only used data for 2001 and for the European non OECD members we rely on the source for 2004.

26 The 1974 amendment to the Federal Election Campaign Act (FECA) introduced the option of full public financing for presidential general election campaigns in return for an acceptance of certain regulations including spending caps, but this option proved to be increasingly unattractive to the candidates. In the 2004 campaign financial activities of Presidential candidates totaled more than \$ 1 billion, whereas federal matching funds amounted to \$28 million thus covering merely $4 \%$ of the total cost of primaries. The two major party nominees received $\$ 74.6$ million each in public funds to conduct their general election, while the two parties received \$ 14.9 million each from the U.S treasury for their nominating conventions (see the section on campaign finance statistics in Federal Election Commission 2005b: 63). Historical accounts of the decreasing role of public funding in the financing of presidential campaigns are given in Corrado 2005a and Corrado 2005b. In the 2008 election all major candidates refused federal matching funds for the primaries, while Senator Barack Obama became the first candidate to refuse government funds for the general election.

27 Non parametric regression can be used to explore the relationship between two variables without making assumptions on the functional form of the relationship. Several techniques for non parametric regression analysis exist. The technique we have used is Cleveland's (1979) "locally weighted scatterplot smoother" (LOWESS).

28 This is in line with recent research by Andrea Louise Campbell $(2002 ; 2003)$ investigating the mobilizing effects of social security and showing that those who are more dependent upon public programs are more active.

29 The wording of the question varies between surveys. The ESS and CESES surveys asked how satisfied the respondents were with the way democracy works in their country, while the 2004 ISSP asked how the respondents think democracy works in their country. In Figure 6 we have therefore separated the results of the ISSP from the two other surveys.

30 These figures are sensitive to the different wording of the respective question in various surveys. 


\section{Bibliography}

Alber, Jens (2000): Warum die meisten Amerikaner nicht wählen, einige aber doch. Leviathan 28, 3: 319-342.

Adema, Willem and Maxime Ladaique (2005): Net Social Expenditure, 2005 Edition - More comprehensive measures of social support. Paris: OECD. (http://www.oecd.org/dataoecd/ 56/2/35632106.pdf).

Bennet, Stephen E. and David Resnick (1990): The Implications of Nonvoting for Democracy in the United States. American Journal of Political Science 34, 3: 771-802.

Best, Heinrich (2007): New Challenges, New Elites? Changes in the Recruitment and Career Patterns of European Representative Elites. Comparative Sociology 6: 85-113.

Best, Heinrich and Maurizio Cotta (eds.) (2000): Parliamentary representatives in Europe 18482000. Legislative recruitment and careers in eleven European countries. Oxford: Oxford University Press.

Campbell, Andrea Louise (2002): Self-Interest, Social Security, and the Distinctive Participation Patterns of Senior Citizens. The American Political Science Review 96, 3: 565-574.

Campbell, Andrea Louise (2003): Participatory Reactions to Policy Threats: Senior Citizens and the Defense of Social Security and Medicare. Political Behavior 25, 1: 29-49.

Cleveland, William S. (1979): Robust Locally Weighted Regression and Smoothing Scatterplots. Journal of the American Statistical Association, 74: 829-836.

Corrado, Anthony (2005a): Money and Politics: A History of Federal Campaign Finance Law; pp. 7-47 in Anthony Corrado/Thomas E. Mann/Daniel R. Ortiz/Trevor Potter/Frank J. Sorauf: The New Campaign Finance Sourcebook. Washington, D.C.: Brookings Institution Press.

Corrado, Anthony (2005b): Public Funding of Presidential Campaigns; pp. 180-204 in Anthony Corrado/Thomas E. Mann/Daniel R. Ortiz/Trevor Potter/Frank J. Sorauf: The New Campaign Finance Sourcebook. Washington, D.C.: Brookings Institution Press.

Davidson, Roger H. und Walter J. Oleszek (1998): Congress and Its Members. Sixth Edition. Washington, D.C.: Congressional Quarterly Inc.

Davidson, Roger H. und Walter J. Oleszek (2006): Congress and Its Members. Tenth Edition. Washington, D.C.: Congressional Quarterly Inc.

Federal Election Commission (2005a): Federal Elections 2004. Election Results for the U.S. President, the U.S. Senate and the U.S. House of Representatives. Washington: Federal Election Commission. (http://www.fec.gov/pubrec/fe2004/federalelections2004.pdf).

Federal Election Commission (2005b): Federal Election Commission Annual Report 2004. Online. Available HTTP: <http://www.fec.gov/pdf/ar04.pdf> (accessed 30 June 2008).

Federal Election Commission (2008): Public Funding of Presidential Elections, Online. Available HTTP: < http://www.fec.gov/pages/brochures/ public_funding_brochure.pdf> (accessed 26 June 2008).

Ferejohn, John A. and Morris P. Fiorina (1975): Closeness Counts Only in Horseshoes and in Dancing. American Political Science Review 69, 3: 920-925.

Franklin, Mark (2004): Voter Turnout and the Dynamics of Electoral Competition in Established Democracies since 1945. Cambridge: Cambridge University Press.

Glazer, Nathan (1988): The American Welfare State: Incomplete or Different?; pp. 168-194 in Nathan Glazer (ed.): The Limits of Social Policy. Cambridge: Harvard University Press.

Gray, Mark and Miki Caul (2000): Declining voter turnout in advanced industrial democracies, 1950 to 1997 - The effects of declining group mobilization. Comparative Political Studies 33, 9: 1091-1122. 
Jackman, Robert W. (1987): Political Institutions and Voter Turnout in the Industrial Democracies. American Political Science Review 81, 2: 405-423.

Kirchgässner, Gebhart (1990): Hebt ein "knapper" Wahlausgang die Wahlbeteiligung? Eine Überprüfung der ökonomischen Theorie der Wahlbeteiligung anhand der Bundestagswahl 1987.; pp. 445-447 in Max Kaase/Hans-Dieter Klingemann: Wahlen und Wähler. Analysen aus Anlass der Bundestagswahl 1987. Opladen: Westdeutscher Verlag.

Klass, Gary M. (1985): Explaining America and the Welfare State: An Alternative Theory. British Journal of Political Science, 15, 4: 427-450.

Kohler, Ulrich (2006): Die soziale Ungleichheit der Wahlabstinenz in Europa; pp. 159-179 in Jens Alber and Wolfgang Merkel (eds.): Europas Osterweiterung: Das Ende der Vertiefung? Berlin: Edition Sigma.

Leighly, Jan and Nagler, Jonathan (2007): Unions, Voter Turnout, and Class Bias in the U.S. Electorate, 1964-2004. The Journal of Politics 69, 2: 430-441.

Lijphart, Arend (1997): Unequal participation: Democracy's unresolved dilemma - Presidential Address. American Political Science Review, 91: 1-14

Lipset, Seymour Martin (1969): Political Man. London: Heineman.

Lipset, Seymour Martin (1996): American Exceptionalism. A Double-Edged Sword. New York London: Norton.

Lipset, Seymour Martin and Gary Marks (2000): It Didn't Happen Here. Why Socialism Failed in the United States. New York - London: Norton.

McDonald, Michael and Samuel L. Popkin (2001): The Myth of the Vanishing Voter. American Political Science Review 95, 4: 963-974.

Oppenhuis, Erik V. (1995): Voting Behaviour in Europe: A Comparative Analysis of Electoral Participation and Party Choice. Amsterdam: Het Spinhuis.

Piven, Frances Fox and Richard A. Cloward (1988): Why Americans Don't Vote. New York: Pantheon Books.

Piven, Frances Fox and Richard A. Cloward (2000): Why Americans Still Don't Vote. Boston: Beacon Press.

Powell, G. Bingham (1986): American Voter Turnout in Comparative Perspective. American Political Science Review, 80: 17-43.

Rifkin, Jeremy (2004): The European Dream. How Europe's Vision of the Future is Quietly Eclipsing the American Dream. New York: Tarcher/Penguin.

Shaffer, Stephen D. (1982): Policy Differences between Voters and Non-Voters in American Elections. The Western Political Quarterly 35, 4: 496-510.

Shipler, David K. (2004): The Working Poor. New York: Vintage Books.

Sombart, Werner (1906) Warum gibt es in den Vereinigten Staaten keinen Sozialismus. Tübingen: Mohr.

U.S. Census Bureau (2007): Statistical Abstract of the United States 2007. (http:// www.census.gov/prod/www/statistical-abstract.html).

Verba, Sidney (2003): Would the Dream of Political Equality Turn out to Be a Nightmare? Perspectives on Politics 1, 4: 663-679.

Wells, Herbert George (1906): The Future in America. New York: Harper \& Brothers.

Verba, Sidney (2003): Would the Dream of Political Equality Turn out to Be a Nightmare? Perspectives on Politics 1, 4: 663-679.

Wilensky, Harold L. (2002): Rich Democracies. Political Economy, Public Policy, and Performance. Berkeley - Los Angeles - London: University of California Press. 
The Research Area "Education, Work, and Life Changes" comprises the Research Units "Labour Market Policy and Employment", "Inequality and Social Integration" and "Skill Formation and Labor Markets", the Research Groups "Public Health" and "Education and Transitions into the Labour Market", the Research Professorships "Demographic Development, Social Change, and Social Capital" and "Social and Political Theory", and the Emmy Noether Junior Research Group "'Love', Work, Recognition - Recognition and Inequality in Dual-Career Couples".

\section{Research Unit Inequality and Social Integration}

\section{Discussion Papers 2008}

Petra Böhnke, Ulrich Kohler Well-being and Inequality Order No.: SP I 2008 - 201

Jens Alber, Ulrich Kohler The inequality of electoral participation in Europe and America and the politically integrative functions of the welfare state

Order No.: SP | $2008-202$

\section{Discussion Papers 2007}

Richard Rose

Evaluating Democratic Governance: A Bottom Up Approach to European Union Enlargement

Order No.: SP | 2007 - 201

\section{Petra Böhnke}

Poverty and Social Integration in the Enlarged Europe

Order No.: SP | $2007-202$

Petra Böhnke

Policy or Privacy - What Matters Most

for Individual Well-Being?

Order No.: SP | $2007-203$

Marco Albertini, Chiara Saraceno

Contact between adult children and their divorced parents: Italy in a comparative perspective

Order No.: SP | $2007-204$
Jens Alber

Where Turkey stands in Europe and why it should be admitted to the EU Order No.: SP I $2007-205$

\section{Discussion Papers 2006}

Stein Ringen

Reflections on Inequality and Equality

Order No.: SP | 2006 - 201

\section{Discussion Papers 2005}

Ricarda Nauenburg

Globalisierung und rechtspopulistische Wahlerfolge

Order No.: SP | $2005-201$

Eckhard Priller, Jana Sommerfeld Wer spendet in Deutschland? Eine sozialstrukturelle Analyse Order No.: SP | 2005 - 202

Jan Delhey

A trade-off between enlargement and integration? An analysis of trust between EU nationalities Order No.: SP I 2005 - 203

Jan Delhey, Urlich Kohler From Nationally Bounded to PanEuropean Inequalities? On the Importance of Foreign Countries as Reference Groups

Order No.: SP I 2005 - 204 
Discussion Papers 2004

Jan Delhey

European Social Integration.

From convergence of countries to

transnational relations between people

Order No.: SP | 2004 - 201

Jan Delhey, Kenneth Newton

Social Trust: Global Pattern or Nordic

Exceptionalism?

Order No.: SP | 2004 - 202

Ulrich Kohler

Empirische Untersuchung zweier Individualisierungshypothesen mit Querschnittsdaten aus 28 Ländern

Order No.: SP I 2004 - 203

Discussion Papers 2003

Harold L. Wilensky

Postindustrialism and

Postmaterialism? A Critical View of the

"New Economy", the "Information

Age", the "High Tech Society", and All

That

Order No.: SP I 2003 - 201

Wilhelm Hinrichs

Ausländische Bevölkerungsgruppen in Deutschland. Integrationschancen 1985 und 2000

Order No.: SP | 2003 - 202 